\title{
ACHIEVING SUSTAINABLE CONSTRUCTION WITHIN PRIVATE FINANCE INITIATIVE (PFI) ROAD PROJECTS IN THE UK
}

\author{
Rifat Akbiyikli', David Eaton², Seyyit Umit Dikmen ${ }^{3}$
}

\author{
${ }^{1}$ Department of Civil Engineering, Sakarya University, 54187 Adapazari, Turkey \\ ${ }^{2}$ University of Salford, School of the Built Environment, Maxwell Building, Salford, M5 4WT - UK \\ ${ }^{3}$ Department of Civil Engineering, Istanbul Kultur University, Bakirkoy 34156, Istanbul, Turkey \\ E-mails: ${ }^{1}$ rakbiyikli@sakarya.edu.tr (correspondingauthor); ${ }^{2}$ d.eaton@salford.ac.uk; ${ }^{3}$ u.dikmen@iku.edu.tr
}

Received 31 August 2010; accepted 10 May 2011

\begin{abstract}
The construction industry is facing the challenge of increasing demands of its sustainability performance. The construction and maintenance of the built environment has substantial impact on the sustainability of the environment. Meanwhile, public sector clients are increasingly asking for a sustainable approach in their specification and procurement decisions, sustainability is still seen as a novel concept within the construction industry in many parts of the world without a settled definition. The premise of this study is that the interaction between road projects realized by the private finance initiative and their delivery in the UK improve sustainability. The paper, based on the case study research, explains the sustainability implementation in two PFI road projects and demonstrates that the PFI mechanism facilitates sustainable implementation to a far greater extent than is achievable using traditional procurement methods.
\end{abstract}

Keywords: built environment, construction, economy, private finance initiative, sustainability, roads.

Reference to this paper should be made as follows: Akbiyikli, R.; Eaton, D.; Dikmen, S. U. 2012. Achieving sustainable construction within private finance initiative (PFI) road projects in the UK, Technological and Economic Development of Economy 18(2): 207-229.

JEL Classification: O18, O52, R11, R42, R51.

\section{Introduction}

It is hard to define 'sustainability' exactly, but arguing over definitions does not advance the debate. However, the concern over sustainability of the world we pass on to future generations continues to grow. A more sustainable future is generally accepted to mean a cleaner environment, a safer, and more cohesive and inclusive and economically more successful and resourceful society. These key concerns represent the three legs of the sustainability 'stool' environmental, social and economic (BRE 2002; Viteikienè, Zavadskas 2007). 
The construction industry and the built environment should be considered as two major areas that needs close attention for the achievement of a sustainable development in the societies to which we belong (CIB 1999).

It is a widely accepted fact that, the construction industry is one of the most resource intensive industries. At the same time this need for resources puts the industry in the vanguard of environmentally damaging industries in the world. Construction annually accounts for $40 \%$ of the total amount of raw materials needed in the global economy. The majority of these materials are stone, gravel, sand, clay, iron ore and other quarried material (Rodman, Lenssen 1995). The construction industry has been identified as the focus for attention since creating and running the built environment accounts for about half of all energy used and approximately half of all landfill (CIRIA 2001).

In the European Union, construction is the largest industrial sector, producing approximately $11 \%$ to the Union's GNP and having more than 25 million people directly and indirectly engaged (CIB 1999).

Whereas in the UK, the Department of the Environment, Transport and the Regions (DETR) states that UK construction sites and demolition produce 72 million tonnes of waste each year which represents $17 \%$ of the UK's total waste burden (DETR 2000). Commercial waste from construction adds up to 30 million tonnes, a further $7 \%$ of the UK total. Poor design and site management leads to 10 million tonnes of non-used materials each year that are delivered to vacant sites (Howard 2000; BRE 2002). The construction industry produces annually three times the waste produced by all UK households combined (DTI 2004, 2006).

As noted by Parkin, the construction industry is facing pressure to increase the sustainability of its practice (Parkin 2000). This pressure implies a major change in the industry's understanding of society's demands and its clients and in its own sense of corporate social responsibility in its work practices. The construction, maintenance and use of buildings and infrastructure impacts substantially on our environment and is currently contributing significantly to irreversible changes in the world's climate, atmosphere and ecosystem (BRE 2002). According to Saparauskas and Turskis the sustainable construction conception can vary according to the country's size, level of economic development, social, cultural and other factors (Saparauskas, Turskis 2006).

The premise of this study is that the interaction between road projects realized by the private finance initiative and their delivery in the UK improve sustainability. This paper, based on case study research, explains the sustainability implementation in a PFI road project and demonstrates examples of sustainability implementation in a series of PFI road projects in the UK. The mechanism of PFI facilitates sustainable implementation to a far greater extent than is achievable using traditional procurement methods.

\section{Sustainable development}

In 1983 the United Nations (UN) General Assembly passed resolution 38/161 leading to the establishment of a special commission widely known as the Brundtland commission after the name of its chair Gro Harlem Brundtland. The commission's main task was "to make available a report on environment and the global problematique to the year 2000 and 
beyond including proposed strategies for sustainable development". This assignment was the recognition of the UN General Assembly that environmental problems were global in nature and determined that it was in the common interest of all nations to establish policies for sustainable development. The commission prepared a comprehensive report titled Our Common Future, also publicly known as the Brundtland report, attracting the world's attention to the urgency of making progress toward economic development that is sustainable without depleting natural resources or harming the environment. The report provided a key statement that described the sustainable development as, "development that meets the needs of the present without compromising the ability of future generations to meet their own needs" (UN Report A/42/427 1987).

Consequently, as listed in the report, the following requirements were set forth for the pursuit of a sustainable development:

- a political system that secures effective citizen participation in decision making;

- an economic system that is able to generate surpluses and technical knowledge on a self-reliant and sustained basis;

- a social system that provides for solutions for the tensions arising from disharmonious development;

- a production system that respects the obligation to preserve the ecological base for development;

- a technological system that can search continuously for new solutions;

- an international system that fosters sustainable patterns of trade and finance; and

- an administrative system that is flexible and has the capacity for self-correction.

Thus, an acknowledgement has been made in the report to the three fundamental components of sustainable development, namely environmental protection, economic growth and social equity.

In June 1992, the United Nations Conference on Environment and Development (UNCED), also known as the Rio Earth Summit declared that "the right to development must be fulfilled so as to equitably meet developmental and environmental needs of present and future generations". The objectives of the conference were to build upon the hopes and achievements of the Brundtland Report. Hence, Rio reiterated that sustainable development is not just about the environment, but also about the economy and society as well. During the summit, it was also highlighted that the preservation of the natural resource base is critical for both economic and social progress. Meanwhile, the preservation of the natural resource base can only be achieved through the prevention of the degradation of the environment by effective measures (The Earth Summit 1992).

Among the documents produced in Rio, the Declaration on Environment and Development, shortly known as the Rio Declaration, consisted of 27 principles with the intent to guide the future sustainable development around the world. The second document the "Agenda 21" programme was adopted by 178 states at the Summit. The programme is a comprehensive plan of action in all areas in which humanity impacts on the environment. This plan was further reaffirmed at the next World Summit on Sustainable Development (WSSD) held in Johannesburg, South Africa from 26 August to 4 September 2002. The third important docu- 
ment produced at the Summit was the "Framework Convention on Climate Change" which paved the way to the 1997 Kyoto protocol.

In the 2005 World Summit, it was reiterated that development is the main goal, yet the sustainable development with its economic, social and environmental aspects should constitute the main inspiration and the agenda of the activities of United Nations. It was also stated that good governance and the rule of law both at the national and international levels are necessary for the eradication of poverty and hunger, sustainable economic growth and development (UN World Summit 2005).

In lieu of outcomes from UN summits, sustainable development can be described as a concept of using the natural resources to meet the human needs while preserving the environment and assuring that the needs can be met both today and in the future. In fact, owing to the valuable efforts made by United Nations and numerous organizations, this concept seemingly has received wide acceptance and today it is becoming a central concern for all including individuals, managers and law makers. Yet, construction, maintenance and use of the built environment have a substantial impact on the environment and can create major irreversible changes in our environment including climate and ecosystems.

\section{The construction sector and sustainability}

In the 1980's, more attention was given to technical issues in construction such as materials, building components and energy related design concepts. However, starting from the mid 1990's an appreciation of the significance of the non-technical issues, namely the "soft" issues was growing. These "soft" issues are essential for sustainable development in construction.

Sustainability is still seen as a novel concept within the construction industry with no settled definition and no settled body of existing practice and processes. The industry has to understand what sustainability is in its context and focus on creation, sustaining and dissemination of knowledge for sustainable construction across the multiple stakeholders involved in construction projects. There is a growing realization and acceptance throughout different societies that there is a need for a more responsible approach to the environment. This new trend embraces societal and economic issues, under the umbrella concept of sustainability and sustainable development.

Kibert (1999) summarised the aims of a sustainable construction practice in the following principles:

- minimisation of resource consumption;

- maximisation of resource reuse;

- use of renewable recyclable resources;

- protection of the natural environment;

- creation of a healthy and non-toxic environment; and

- pursuit of quality in creating the built environment.

The European Construction Industry Federation (FIEC) in a declaration titled "The FIEC Principles for Sustainability" named economic, social and environmental aspects of sustainability as the 3 pillars of the structure (FIEC 2005). In the same publication the following recognitions were made about these pillars: 


\section{The Economic Pillar:}

- the construction industry accounts for an estimated 9.9\% of GDP and provides $50.8 \%$ of Europe's gross fixed capital formation;

- in order to develop in a sustainable manner, legislators and public authorities should ensure that firms are able to operate within an adequate and balanced regulatory framework and a fair competitive environment;

- a prerequisite for sustainable development is a healthy economic environment, in which enterprises can develop their commercial activities and raise their profitability.

\section{The Social Pillar:}

- it consists of 2.4 million enterprises, within EU-22 (EU members in 2006 excluding Latvia; Lithuania and Malta), of which 97\% are SMEs with fewer than 20 employees, making the construction industry Europe's largest industrial employer;

- this implies significant responsibility for social issues, in particular training, health and safety of its estimated 14 million operatives (EU 22) accounting for $7.2 \%$ of total employment.

\section{The Environmental Pillar:}

- about $50 \%$ of the raw materials taken from the Earth's crust are used in construction;

- the built environment produces approximately one third of all greenhouse gas emissions;

- the waste arising from construction and demolition activities constitutes one of Europe's largest waste streams, the larger proportion of which is, however, recycled.

Construction makes an immense contribution to everyone's quality of life and in enabling the positive impacts of its work to be achieved in a more sustainable manner. Construction outputs alter the nature, function and appearance of towns and countryside. This is realized by an extensive supply chain and large number of stakeholders. Health and safety, multiple environmental aspects, community development, social accountability, ethics and integrity, labour rights and corruption, and stakeholder engagement, can be listed as part of the sustainability issues that concern the construction companies. As noted earlier, the construction industry is Europe's largest industrial employer which implies that it has specifically more extensive social responsibilities than all other industrial sectors. Moreover, the fact that construction accounts for around 50\% of Europe's annual capital investment, implies that its immense environmental impacts need to be carefully managed. The construction industry is able to provide solutions for most of these economic, social and technical challenges resulting from these impacts, but at the same time it emphasises that a joint effort of all actors concerned is necessary in order to achieve more realistic and sustainable results (FIEC 2005).

The construction industry needs to develop and implement innovative design and construction methods to reduce the social effects of its business. It needs to consider the economic impact of sustainable project implementation, environmental and social impacts of large scale projects, the efficiency of the resources and sustainable building and infrastructure design and materials. PFI to which we will return later, has an implied mechanism to permit the evaluation of these requirements. More traditional forms of procurement are generally premised only on effective economic delivery. 
The CIB (1999) notes that Agenda 21 paragraph 25 requires that governments should encourage the construction industry to promote "locally available, appropriate, affordable, safe, efficient and environmentally sound construction methods and technologies in all countries.... To emphasize optimal use of local human resources and to encourage energy saving methods that is protective of human health". Paragraphs 69, 70 and 71 specifically set out actions for government and the construction industry regarding planning, design, construction, maintenance and rehabilitation; the procurement, use and promotion of sustainable building materials and the production of sustainable materials.

For the construction sector, these aims can be translated into specific goals including maintaining the health and well-being of the construction workforce, pollution control, waste minimisation, and efficient construction processes leading to projects that are delivered to time and budget, and efficient to operate. However, considerations need to go beyond the construction phase to cover lifetime sustainability of buildings and infrastructure, including the requirements of owners, operators and users (CIRIA 2006; Edelenbos, Klijn 2009; Robichaud, Anantatmula 2011).

As presented in Agenda 21, sustainable construction adopts different priorities in different countries. Furthermore, there are widely different views and interpretations between developed and transition and developing countries. The developed economies are in a position to devote more attention to creating a more sustainable building stock by upgrading, by new developments or the use of new innovative technologies (CIB 1999; Robichaud, Anantatmula 2011). In this study, attention will be limited to the applications in PFI financed road projects in the UK.

\section{UK legislation related to sustainability in construction sector and built environment}

There are some important legal arrangements in UK legislation that promote and encourage sustainable construction. Three of these relating to activities of the construction sector will be briefly explained here.

The Landfill Tax: When introduced in 1996, the intent was to influence waste management practices by greater diversion of construction waste from landfill and hence encouraging re-use and recycling of materials through more innovative means. When enacted, the cost of 'active waste' fill was set at $£ 7.00$ per tonne while inactive waste attracted a tax of $£ 2.00$ per tonne. In 1999 , the active waste rate was increased to $£ 10.00$ per tonne and through an annual cost escalation; it rose further to $£ 15.00$ per tonne by 2004 (CIRIA 2001). In 2011 the current rate is $£ 48$ /tonne and will increase by a further $£ 8.00$ /tonne/annum until at least 2013 (HMRC 2011).

The Climate Change Levy: It was ratified in April 2001. It is a tax on energy delivered to business users in the UK. It provides an incentive for more efficient use of energy and to reduce carbon emissions (CIRIA 2001). It is a variable tax levied on companies' use of electricity, gas or other supplied fuels. As an example a levy of just under $0.50 \mathrm{p} / \mathrm{KW} / \mathrm{hr}$ is charged for electricity (HMRC 2011). 
The Aggregates Levy: Introduced in April 2002 to encourage the supply and use of alternative materials by reflecting the environmental costs of quarrying (CIRIA 2001). A basic charge of $£ 2.00$ /tonne is charged on all quarried aggregate (HMRC 2011).

These levies have a direct and immediate effect on the utilisation of resources within the construction sector.

\section{The role of public procurement in sustainability}

Public procurement can play a key role in driving innovation in environmental technologies, by bridging the problematic gap between demonstration projects and market commercialisation. A commitment by the Government to procure environmental technologies on a significant scale for new public buildings would help unblock investment and hence the innovation chain (Hill, Bowen 1997; Rwelamila et al. 2000; Yuan et al. 2009, 2010).

It is suggested by the Green Alliance "The business case should demonstrate that any specified environmental standards are reasonable, achievable and cost effective. It will also need to present any cost assumptions relating to a Public Sector Comparator (PSC) for the project. The inclusion of sustainable technologies with what might appear to be higher up front capital costs will need to be explained in terms of their cost effectiveness over the lifetime of the contract and the environmental benefits they deliver" (Green Alliance 2004). Indeed it is very true that the business should be convinced that the measures they will take for sustainability will be beneficial for them in the long run. However, very few standardised construction contracts are currently predicated on whole life cycle costs, or indeed on the basis of contractor suggested changes. The PFI mechanism requires the contractor to design, build, finance and operate a project for an extended period of time - frequently in the order of 25-35 years. This provides the contractor with a major incentive to consider whole life cycle costs and to innovate with sustainable solutions. Examples of this within PFI roads are provided later.

However, sustainable procurement is about embedding the principles of sustainable development into spending and investment decisions across the whole of the public sector. Efficiency has always been an essential feature of public spending. Yet spending decisions taking into account the 3 pillars of sustainability, namely environmental, social and the economic pillars can deliver significantly enhanced value for money for the public purse.

The Green Alliance suggests that "All public procurement should be made consistent with Government policies for delivering sustainable development, most notably in terms of carbon reduction, waste minimisation, water efficiency, community regeneration and social inclusion. PFI has a key role to play within procurement due to the scale of investment involved; the greater ease of influencing the small number of actors involved; and the way in which PFI contracts secure the long-term engagement of contractors" (Green Alliance 2004).

However, the Green Alliance goes on to say, "Sustainability considerations are not sufficiently embedded in the PFI process to ensure consistent delivery, and success is highly reliant on the motivation and expertise of individual public sector clients and private contractors" (Green Alliance 2004). This is a criticism of the lack of maturity of the PFI mechanism rather than any inherent issue within PFI. 
Pursuing sustainability requires a continuous process of change. Hence, the construction industry is facing ever-increasing demands to improve its sustainability performance. Public sector clients are increasingly asking for a sustainable approach in their specification and procurement decisions. PFI is an available mechanism that encourages this.

\section{PFI roads}

The Private Finance Initiative (PFI) was launched in the early 1990's in the UK, as a legal framework for concessions in the UK to encourage private capital investment into the construction industry. In the PFI framework, the public sector defines the output specification for the services to be purchased from the private sector with a predefined payment mechanism. The public purchases a service not an asset.

The aim of introducing the PFI in the UK was to achieve closer partnering between the public and private sectors at both central government and local authority levels. The intention was to increase the flow of capital to projects against a background of restraint on public expenditure by utilizing private sector money and management skills. However, PFI is not a mechanism of borrowing money from the private sector. It is all about creating a structure in which improved Value for Money (VfM) is achieved through private sector innovation and management skills delivering significant performance improvements and efficiency savings.

PFI is an innovative procurement route that can be used for the development of major highway works. PFI will be considered in the context of each major party of a typical DesignBuild-Finance-Operate (DBFO) scheme and set against the key criteria of appropriate quality.

Quality schemes are key drivers in improving performance in the public sector (Highways Agency 2004). PFI achieves the integration between the design, build and service operation, to incorporate innovative design, re-engineering, avoidance of over specification, the implementation of new materials, more efficient management, to guarantee maintenance at the appropriate time (HM Treasury Taskforce 1999). PFI is a contract-based model which adheres to the spirit of New Public Management (NPM) reform. Hood (1995) identified the reliance on ideological, political and administrative reforms, which came under the umbrella of the NPM, on private sector styles of management practice, discipline and prudence in resource use; explicit formal measurement standards and measures of performance and emphasis on outputs controls. Typical NPM initiatives in the UK are Best Value, PPP/PFI, Resource Accounting and Resource Budgeting. In this paper PFI demonstrates the success of NPM in UK road projects. PFI encourages good long-term quality due to the concessionaire being bound to an extended term of maintenance (typically 30 years). In traditional procurement forms maintenance was frequently neglected, due to the lack of a specific maintenance budget, resulting in deteriorating road quality as a result of the maintenance not being carried out at the appropriate time. Hence, sustainability was frequently sacrificed to financial austerity.

The contract specifications for a PFI road project being performance specifications generally provide the opportunity and freedom for potential bidders to propose innovative solutions which integrate the design, construction, operation and maintenance. In some cases, the main outputs may be sustainable objectives, for example targets for recycling, waste management, etc. and may require bidders as part of their method statement, to explain how 
they will comply with the environmental requirements in the specification. This might involve preparation of an environmental impact assessment by bidders of their proposed work. The final business case of the PFI project will present all the relevant information which will enable a decision to be made about a contract award. The business case will therefore need to take account of the environmental requirements of the project, and in its final form, to provide an assessment of the preferred option with appropriate commentary. This provision is not available in traditional forms of procurement.

It is expected that sustainable policies and both the regulatory and the legal frameworks concerning the environment will be tightened in the near future. In some cases, it might even affect ongoing contracts. Yet such tightening does not necessarily mean an increase in the costs. Since the PFI projects generally last long periods of time, such as $25-30$ years, the company (in this case the contractor) may miss a great opportunity to reduce the life cycle (in this case the contract period costs) of the project by not effectively using the advantages offered by the laws and regulations concerning sustainability. Traditional procurement forms have a significantly shorter contractor involvement period and hence the contractors' incentive to maximise whole life costs is greatly reduced.

\section{Method of evaluation}

As presented above, PFI is a broad topic, which limited the authors to focus predominantly on major highway works under the DBFO form of contract. The achievement of sustainable construction within private finance initiative road projects in the UK will be demonstrated here through two case studies.

Regarding the evaluation of the level of sustainability of a project, there are about half a dozen evaluation methods for buildings (Saparauskas, Turskis 2006; Ding 2008; Ortiz et al. 2009; Yuan et al. 2010; Wang 2011). This is quite understandable since the energy requirements and consumption of buildings (including housing, offices and leisure) especially are much higher than in transport or even industrial facilities (Mickaityte et al. 2008). On the other hand, there are no established methodologies for the assessment of infrastructure projects as for the buildings. Yet, either or both of the two impact assessment techniques, namely the comparative value analysis (also alternatively known as "traffic light approach") by Swiss Federal Council (2008) and the "stretching the web" technique by Defra (2010), as proposed by OECD (2010) can be utilized. In this paper both techniques will be utilized to assess the impact of PFI on sustainability in comparison to traditional procurement system.

It can also be argued that the features of buildings affect sustainability adversely, mainly or at a larger scale in the operational phase (occupancy phase), while to the contrary it appears mainly in the construction phase in road projects. Hence below, the construction phase of the selected cases will be studied.

In the following three sections of the paper, first two case studies from UK PFI Road Projects will be presented and then it will be followed by a sustainability impact analysis to assess the impact of the PFI approach as compared to the traditional approach in lieu of the data derived from these case studies. In the third section, namely section 10 of this paper, a brief discussion of the results will be made in lieu to the data available and the results obtained from the analysis. 


\section{Case studies: UK PFI road projects}

Two cases realized in the UK by PFI mechanisms will be presented here. The information presented below has been obtained through a series of face to face interviews with the parties involved in these projects.

\subsection{Highway A92 - upgrading between Dundee and Arbroath - Scotland}

The A92 between Dundee and Arbroath is a vitally important strategic route for the East Coast of Scotland, serving the towns of Dundee, Monifieth, Carnoustie, Arbroath and Montrose (Fig. 1, Table 1). It also serves as a major route for commercial traffic to these towns, and the ports of Arbroath and Montrose.

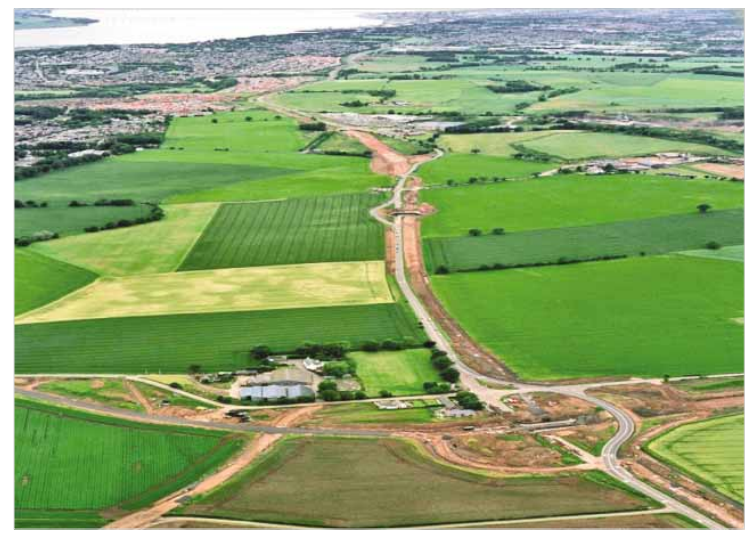

Fig. 1. A92 PFI road project under construction (Courtesy: MorganEST Rugby Office Archive)

Table 1. A92 PFI road project description (Akbıyıklı 2005; Eaton, Akbıyıklı 2005; Akbıyıklı et al. 2011)

\begin{tabular}{ll}
\hline \multicolumn{1}{c}{ Title } & \multicolumn{1}{c}{ A92 Upgrading between Dundee and Arbroath } \\
\hline Location: & Angus Council - Scotland \\
\hline Country: & United Kingdom \\
\hline Project cost: & $£ 150,000,000$ \\
\hline Sector: & Transport - Roads \\
\hline Status: & Completed Nov., 2005 \\
\hline Sponsors \& Concessionaire / & Claymore Roads Ltd. (Morgan = Est + Barclays Bank)/ \\
Lead Manager: & Morgan = Est \\
\hline Purchaser: & Angus Council - Scotland \\
\hline Contractual Package: & $\begin{array}{l}\text { The DBFO (Design, Build, Finance, and Operate) Contract } \\
\text { between Angus Council and Claymore Roads Ltd. The scheme is } \\
\text { let under the Government's Private Finance Initiative (PFI) with a } \\
\text { concession period of thirty years. The project sponsors executed } \\
\text { capitalisation for the project privately }\end{array}$ \\
\hline
\end{tabular}


The previous single carriageway road carried up to 18,000 vehicles per day. The traffic volume increase and the accident record of the existing A92 and associated roads was considered to be a major factor in the continuing decline in economic activity in the area.

A consequence of these problems on the A92 was that traffic was diverting to the less suitable coastal corridor route - the A930. The affected local authorities - Angus Council and Dundee City Council - stated a number of sustainability objectives aimed to improve the safety, quality of life and economic opportunity in the area by upgrading the A92 and carrying out other improvements within the A92/A930 route corridor.

The Construction Sub-Contractor's Early Solutions Together (EST) philosophy has been a guideline during the execution of the works to find the quickest, most effective way to make the A92 achieve the clients' objectives.

A key sustainability requirement of the A92 construction was the large quantities of material needed to form the road structure. Redundant land in the form of a disused airfield provided a 'sustainable solution' for sourcing the necessary material which was recycled and used to form an improvement layer for the road. The unsuitable material from road excavation was used to fill the hole left in the airfield. The fill material was then covered with topsoil creating a new field that could be farmed.

This solution created significant social and economic benefits. It avoided aggregate levy and landfill tax, whilst since becoming operational, the road has not suffered any major vehicular accidents. Travel times between Dundee and Arbroath have been more consistent and ribbon forms of economic development, including housing, have occurred alongside the route.

\subsection{Newport Southern Distributor Road - Wales}

The Newport Southern Distributor Road (NSDR) completed construction in August 2004. It is an upgrading project, consisting of alteration of the existing roads to dual carriageway from Duffryn in the west to the Coldra roundabout in the east and includes a new bridge over the River Usk in Newport City in Wales (Fig. 2, Table 2).

The NSDR - the new dual carriageway is located between junction 24 and 28 of the M4 has been selected by the Department of Trade and Industry as a flagship 'sustainability' case study in Newport (Newport Matters 2004).

The NSDR is recognised by Newport City Council (NCC) as its highest single priority scheme for the improvement of Newport's principal highway network. The NSDR scheme is designed to ease the congestion on the M4 and alleviate heavy traffic problems in and around Newport. This scheme is designed to improve the environment in the city centre, taking traffic away from residential areas, improving access to industrial areas in the East and South of the city and providing a new river crossing. NSDR is the biggest local authority PFI scheme in Wales.

The PFI scheme involves the design, construction, financing and operation and maintenance of a high standard distributor road around the periphery of Newport, including a major new crossing of the River Usk. The Operation and Maintenance Concession is for forty years. 


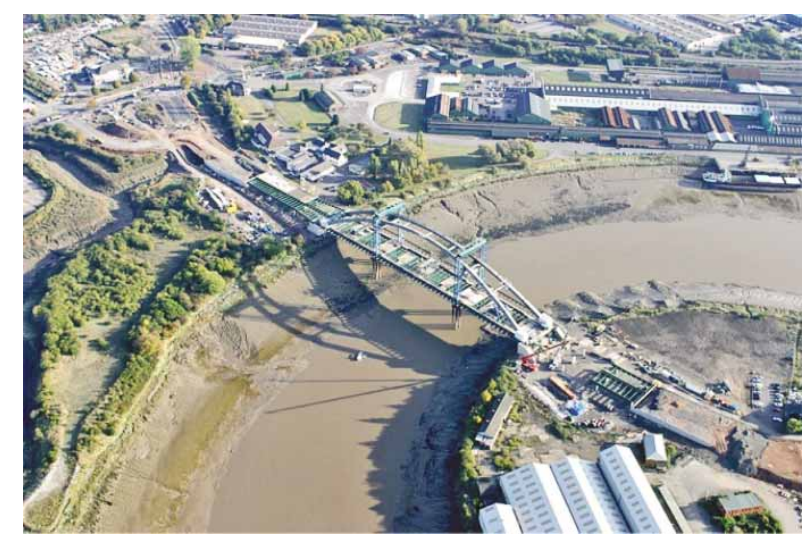

Fig. 2. NSDR PFI road project and River Usk Bridge under construction (Courtesy: MorganEST Rugby Office Archive)

Table 2. NSDR PFI road project description (Akbıyıklı 2005; Eaton, Akbıyıklı 2005)

\begin{tabular}{ll}
\hline \multicolumn{1}{c}{ Title } & \multicolumn{1}{c}{ Newport Southern Distributor Road (NSDR) } \\
\hline Location: & Newport City - Wales \\
\hline Country: & United Kingdom \\
\hline Project Cost: & $£ 200,000,000$ \\
\hline Sector: & Transport - Roads \\
\hline Status: & Construction completed in August 2004 \\
\hline Sponsors \& Concessionaire / & Morgan-Vinci Ltd (Morgan Sindall Investment Ltd and the \\
Lead Manager: & $\begin{array}{l}\text { French construction group Vinci SA) have a 50/50 shareholding } \\
\text { and equity stake }\end{array}$ \\
\hline Purchaser: & Newport City Council - Wales \\
\hline Contractual Package: & $\begin{array}{l}\text { A DBFO (Design, Build, Finance and Operate) Contract } \\
\text { between Newport City Council and Morgan - Vinci Ltd. The } \\
\text { scheme is let under the Government's Private Finance Initiative } \\
\text { (PFI) with a concession period of thirty seven years. The project } \\
\text { sponsors executed capitalisation for the project privately }\end{array}$ \\
\hline
\end{tabular}

The scheme generally follows the line of the existing A4042 carriageway west of the River Usk with an offline section north of the docks, and similarly along the line of the existing A455 east of the river to the Coldra roundabout. A new crossing at the River Usk, forms the central part of the scheme, linking the two roads to provide a direct and continuous carriageway distributor road around the south of Newport.

The sole parties in the PA are Newport City Council (NCC) and Morgan - Vinci Ltd, SPV. The PA (Project Agreement) took effect when it was signed on 29 March 2002 and terminates on the earliest of either:

- 37 years after the Scheduled Permit to Use Date (which is 36 months after the PA was signed), i.e. 01 April, 2042;

- Earlier termination on breach as provided for in the Agreement. 
The project won the Green Apple Award for sustainable construction and was crowned as National Champion for Environmental Best Practice in the Building and Construction sector.

During pre-commencement, the Project Partners jointly searched the maximum possible utilization of the project excavated material. Furthermore, usability of locally available secondary aggregates from sustainable sources such as by-products of the heavy industry historically located in the area was also explored. This has significantly reduced the environmental impact on the community by negating the demand for primary aggregates and reducing long distance haulage movements on the project. As indicated in the publication titled "The Big Picture" by Waste and Resources Action Programme, the NSDR Scheme

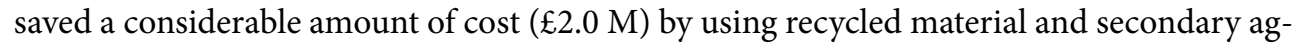
gregates instead of purchasing primary materials (WRAP 2004a, 2004b). Also, in the same publication it is stated that the specific cost savings by using recycled materials in highways maintenance and construction are:

- the avoidance of waste disposal charges and Landfill Tax through the re-use of recycled and secondary materials;

- the avoidance of Aggregate Levy payments, from which recycled and secondary aggregates are exempt;

- reduced cost of transporting aggregates when recovered materials are available locally;

- new recycling techniques have demonstrated cost and performance advantages.

The use of recycled and secondary aggregates guaranteed security of supply and nondependence on quarries. This minimised traffic movement through the route and minimised traffic disruption. Besides the compliance of the materials with the technical specification, there was also a requirement for them to meet the strict environmental guidelines and regulations. Of particular interest was the ecologically sensitive River Usk, which is a Site of Special Scientific Interest and Candidate Special Area of Conservation. Hence, the Local Planning Authority to protect the local environment imposed environmental considerations as conditions of the planning permission.

The project maximized the use of project-derived and locally - available recycled materials to produce direct cost saving (per tonne of aggregate) and indirect cost saving (from the avoidance of the waste disposal charges and landfill tax).

The re-cycled materials are used in general granular fill, capping and unbound sub-base of road building. The re-cycled materials are: concrete aggregate, asphalt, blast furnace slag, steel slag, pulverized fuel ash and spent railway ballast. These re-cycled materials produced well graded granular material (Class 1A); selected coarse graded granular material (Class 6F2); selected granular material (Class 6F3); and granular sub-base material (Type 1).

Overall, $95 \%$ of all aggregates used in the Newport SDR are recycled and secondary materials. This success can be attributed to the geographical location of the principal stockpiles of recycled and secondary aggregates, the ingenuity of the site team, together with a favourable contractual specification. The slag came from a former steel mill in the area, and using it helped pump money back into the local economy. Excavation fill from early work, including old curbing and other concrete or asphalt products, was also used.

In most construction projects, contractors focus on keeping up-front costs low. For this project, however, the lengthy concession period forced the team to think about costs relating 
to the entire life of the project. Because the project depended on toll income calculated on the basis of 68 percent road availability, using materials that required less maintenance and repair meant fewer highway closures and more toll revenue. This "whole-life costing" allowed the contractor to use some high-quality items such as stainless steel columns for the River Usk Bridge.

All materials were tested for their compliance with Specification for Highway Works and that the chemical thresholds agree with those of the Environment Agency's. No departures from the Specifications for Highway Works were required.

The project, through the use of risk assessments provided demonstrable proof that recycled and secondary aggregates are environmentally acceptable and can be used in the vicinity of environmentally sensitive areas without adverse impacts.

In addition to the significant benefits of using locally available recycled and secondary aggregates for the construction project, a number of other benefits also accrued,

- reduction in demand for conventional aggregates, in turn reducing the environmental impact for the community;

- shorter haulage distances, in turn reducing the environmental impact in the local community;

- encouragement of innovation within Morgan Vinci;

- promoting environmental beneficial practices, namely sustainable waste management, within the construction industry.

The utilization of recycled and secondary aggregates on the project is presented in Table 3.

Table 3. Recycled and secondary aggregates in NSDR project (Source: Information given by MorganEST - Rugby Office \& WRAP 2003a, 2003b)

\begin{tabular}{llc}
\hline \multicolumn{1}{c}{ Materials } & \multicolumn{1}{c}{ Application } & Amount (tonnes) \\
\hline Spent railway ballast (unprocessed) & General Granular Fill & 94,938 \\
\hline Spent railway ballast (processed) & Capping Layer & 70,218 \\
\hline Spent railway ballast (processed) & Unbound Sub-base Layer & 30,000 \\
\hline Blast furnace Slag & Unbound Sub-base Layer & 30,000 \\
\hline Steel Slag & Capping Layer & 47,397 \\
\hline Excavations from Brownfield Land & General Granular Fill & 122,062 \\
\hline Recycled Concrete Aggregate & Capping Layer & 7,022 \\
\hline Recycled Asphalt & Capping Layer & 50,908 \\
\hline Total & & 452,454 \\
\hline
\end{tabular}

The use of recycled material did not incur additional capital or maintenance expenditure for the NSDR project; however, it did result in direct cost savings in construction costs, carbon emissions, avoiding landfill costs and health benefits from reduced emissions of PM10 (particles measuring $10 \mathrm{~mm}$ or less). Overall, $£ 2,098,801$ was saved, offset by no costs, which amounted to $3.82 \%$ of savings of the total project cost or $£ 219,609$ per kilometre of road constructed (Fig. 3) (Akbiyıklı, Eaton 2005). 


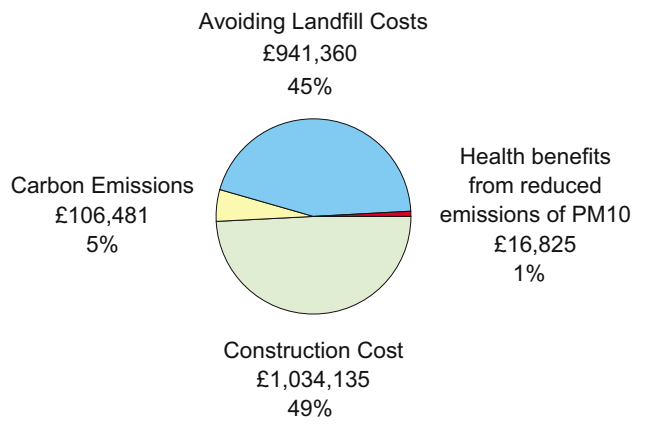

Fig. 3. NSDR project direct savings from recycled material

This sustainable approach reduced materials purchase and transportation costs. Morgan Est raised the profile of environmental best practice throughout its supply chain as part of its continuing process of vendor assessment. All members of the supply chain are made aware of Morgan Est's environmental policy and all sub-contractors that come on site receive an induction that covers environmental and sustainability issues. Additionally the company's procurement team is working towards ensuring that materials are purchased from verified sustainable sources. The team has also started to collect data to identify suppliers that have an environmentally sound record and follow environmental best practice (Akbiyıkl, Eaton 2005).

The Concessioners' outstanding eco-friendly performance and drive to promote environmental best practice throughout the whole project cycles in the NSDR and A92 PFI road projects gave a series of successes at sustainability awards. The environmental effort on the entire NSDR project culminated in a 2004 Green Apple Award for Environmental Excellence in Construction. It marked the first construction award for Wales - and a fitting cap to the project effort.

Morgan Vinci, a joint venture between Morgan Est and construction company Vinci Grands Projects, took two prizes at the Green Apple Environmental Awards for its work on the Newport Southern Distributor Road (NSDR). The award is presented to companies which demonstrate environmental excellence and leadership in their sector.

The above presented 'sustainable solutions' would not have been permitted under traditional procurement forms as the material specifications prescribed new materials. Thus the inherent requirement to maximise whole life cycle within PFI incentivises the contractor to achieve sustainability improvements without necessarily incurring increased costs - hence achieving improved Value for Money for the Local Authorities and significantly improved sustainable construction.

\section{Sustainability impact analysis}

As stated earlier, the PFI and the traditional type procurement methods as applied in the road projects in the UK will be compared through the use of two different sustainability impact analysis methodologies. Both methods cover the three pillars of sustainability through 
a series of questions. Data obtained from the two case studies presented above construed the basis for the analysis.

A slightly different course of analysis has been followed during the use of the methods. In the case of the first analysis, namely the "stretching the web" analysis the answers to the questions reflect the impact of the PFI method in comparison to the traditional method. Where in the "Comparative Value Analysis", both procurement methods, namely PFI and the traditional methods were analyzed separately and compared afterwards.

\section{1. "Stretching the web" analysis}

This analysis method consist a total of 31 questions in the three pillars of sustainability. Out of which 9 are optional user defined questions. In this analysis these 9 questions were not used. The list of the remaining 22 criterion is presented in Table 4 . The answers to the questions range from -2 to 2 , namely indicating significantly negative impact and significantly positive impact. The results of the analysis performed using this technique is given in Figure 4.

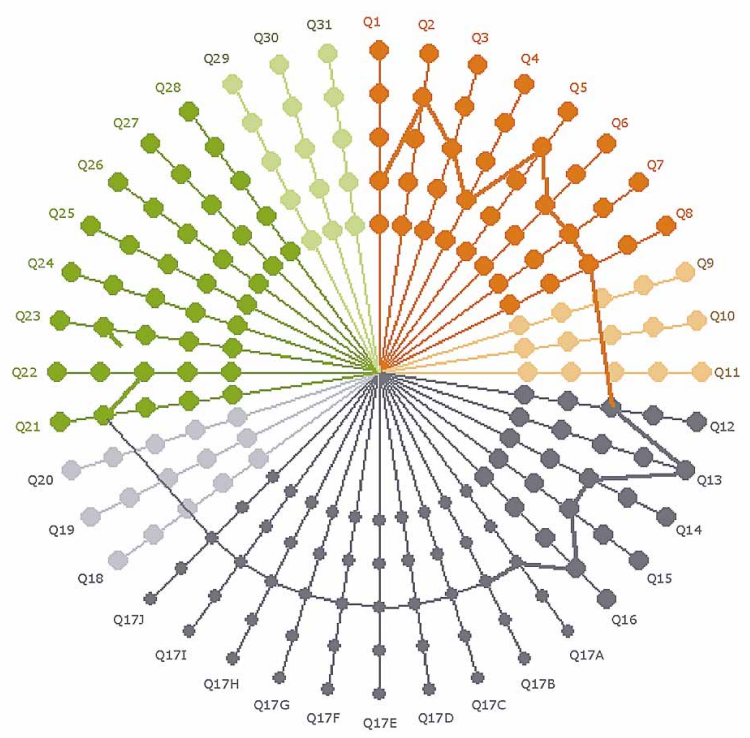

Fig. 4. Results of the stretching the web analysis

In the figure the outermost ring of dots represent the significantly positive impact, i.e. +2 . Likewise, the innermost ring represents the significantly negative impact, i.e. -2 . As can be seen from the figure, PFI scheme's impact on the sustainability is higher or equal to the impact of the traditional scheme in almost all cases except a few. Namely, 6 questions have an impact assessment of +1 as opposed to 2 answers with impact assessment of -1 , the remaining being 0 . 
Table 4. "Strecthing the web" analysis criterion (Defra 2010)

\begin{tabular}{l}
\hline \multicolumn{1}{c}{ Economic impacts } \\
\hline Q1. Will the proposal have a significant impact on competition? \\
\hline Q2. Will the proposal impact on small businesses? \\
\hline Q3. Will the proposal introduce new criminal sanctions or civil penalties? \\
\hline Q4. Will the proposal bring receipts or savings to Government? \\
\hline Q5. Will it impact on costs, quality or availability of goods and services? \\
\hline Q6. Will it impact on the public sector, the third sector, consumers? \\
\hline Q7. Will the proposal result in new technologies? \\
\hline Q8. Will the proposal result in a change in the investment behaviour both into the UK and UK \\
firms overseas and into particular industries? \\
\hline Q12. Will the proposal have an impact on health, wellbeing or health inequalities? \\
\hline Q13. Will the proposal influence safety at work or affect the likelihood of accidents in the \\
community? \\
\hline Q14. Will the proposal affect the rate of crime or crime prevention or create a new offence/ \\
opportunity for crime? \\
\hline Q15. Will the proposal affect the levels of skills and education? \\
\hline Q16. Will the proposal affect the provision of facilities or services that support community \\
cohesion or in other ways that affect the quality of life in the local community? \\
\hline Q17. Could the proposal result in any changes in or a differential impact on any of the following? \\
\hline a. Race equality \\
\hline b. Rural proofing \\
\hline c. Human rights \\
d. Gender equality \\
e. Disability equality \\
f. Children and young people \\
\hline h. Income groups \\
\hline
\end{tabular}

Environmental impacts

Q21. Will the proposal lead to change in the emission of Greenhouse Gases?

Q22. Will the proposal be vulnerable to the predicted effects of climate change?

Q23. Will it lead to a change in the financial costs or environmental and health impacts of waste management?

Q24. Will it impact significantly on air quality?

Q25. Will it involve any material change to the appearance of the landscape or townscape?

Q26. Will it change the degree of water pollution; levels of abstraction of water; exposure to flood risk?

Q27. Will it disturb or enhance habitat or wildlife?

Q28. Will it affect the number of people exposed to noise or the levels of exposure? 


\subsection{Comparative value analysis}

The second method used for the sustainability impact analysis is the method proposed by the Swiss Federal Council (2008). The method uses a 15 point criterion covering the 3 pillars of sustainability, namely economical, environmental and social for the assessment of the impact. For each pillar 5 questions related to sustainability are asked (Fig. 5). The analyst has to assess each criterion on a scale from -3 to 3 , namely significantly negative impact to significantly positive impact. Then the weighted averages of these values represent the sustainability impact of each pillar. Additional criteria can be included in the analysis. However, in this analysis no other additional criteria are included. The results of the sustainability impact analysis based on the Swiss method are presented in Figure 6. As it can be seen from the figure, although the PFI type procurement can be somewhat more expensive and may leave a slightly higher economic burden on the future generations, on the environmental and societal sides of the picture PFI proves to provide a more sustainable solution.

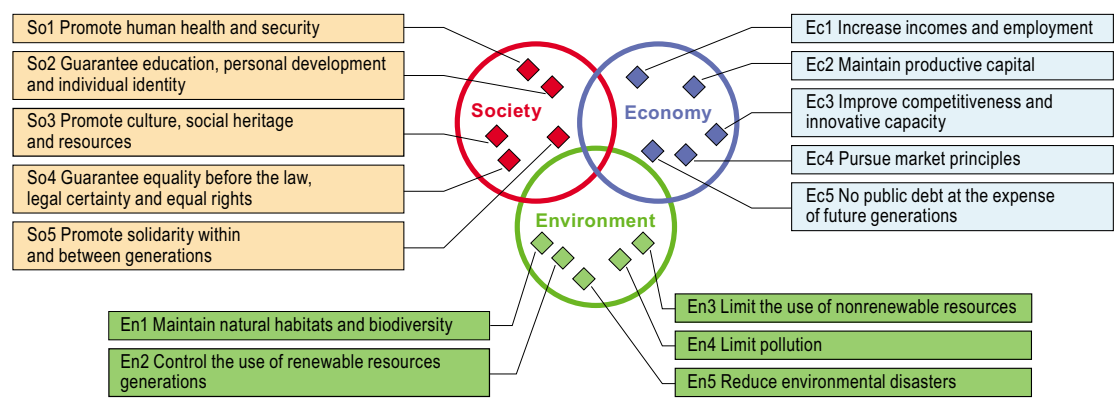

Fig. 5. Swiss Federal Council (2008) criteria for sustainability impact analysis

a)

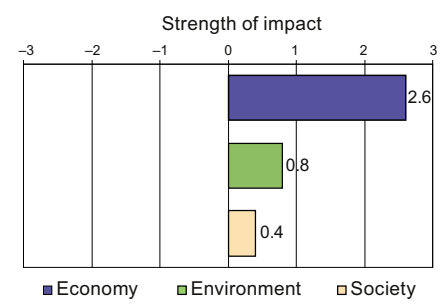

Weighted sum of impacts for traditional type procurement b)

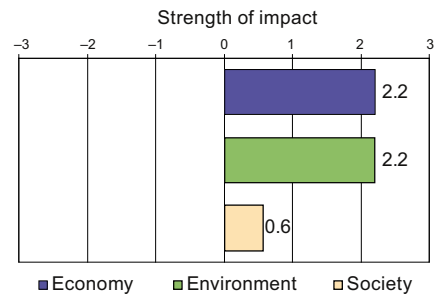

Weighted sum of impacts for PFI type procurement

c)

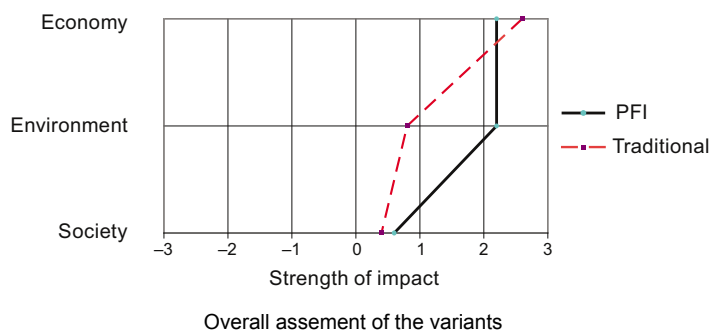

Fig. 6. Sustainability impact analysis of the alternative procurement types for road projects using Swiss criteria 


\section{Discussion of results}

The sustainability impact of the PFI scheme as compared to the traditional method of procurement has been analyzed through two case studies realized in the UK as presented above. For the purposes of the study, a limited number of interviews were undertaken in both cases that formed a basis for the sustainability impact methodology. The size of the sample was not a representative sample of the reflections of all the professions held within the industry, which restricted the scope and scale of information provided. However, it did cover the major stakeholders, the client, the SPV, and the concessions operation and maintenance contractor.

This approach presents a transparent and valid instrument for the holistic impact evaluation, and readily lends itself to further improvement and optimization as information and subsequent experience is gained in the operation of PFI.

The data obtained from the cases studied were used in sustainability impact analysis by two different methods. It demonstrated that the PFI scheme is more successful in leading to sustainable construction as opposed to the traditional form of procurement. Whilst it is accepted that there is some marginal 'loss' in economic terms this disadvantage is far outweighed by the social and environmental benefits, indeed one of the most fundamental qualitative findings of the interviews was that the parties would wish to continue to contract in the same form in the future.

The sustainability assessment has, in this case, been conducted post-hoc, but there is no reason why the same comparison could not be done prior to contracting, to optimize the sustainable development opportunities of a scheme. This would permit the evaluation of social, economic and environmental impacts and allow for the 'trade-off' between categories, in a rational, logical and explicit format, informing the project sponsor prior to contracting. It is possible that the triple-bottom line could subsequently be extended to the sextuple-bottom line of Social, Legal, Economic, Environmental, Political and Technological factors.

The post-hoc evaluation did reveal some conflicts between economic and social and environmental issues. This led to the identification of 'economic loss' when compared to the alternative traditional form of procurement. However, if pre-contract applied, this method could be used to identify potential conflicting goals and permit the determination of methods of optimizing the overall sustainability before execution and minimizing any 'losses'.

A major feature of this approach is that it is rooted in the systematic capture of: direct; indirect, endogenous, exogenous, desirable and undesirable effects, including the incorporation of 'political exigencies'. This multi-attribute, weighted approach can be maximized for particular combinations of features, such that the assessment is tailor-made for a particular project and its environment, rather than being force-fitted into a standardized technique. (The additional questions can be utilized for this purpose). In one of these cases the client acknowledged that PFI was the only economic option available to them, any other form of procurement would not have been feasible - 'the only show in town' syndrome.

The analysis shows that overall PFI is a rationally viable sustainable procurement approach, when assessed carefully:

- the analysis shows that this approach is highly relevant, and a straightforward means of establishing a project's relevance in sustainability terms; 
- it demonstrates an impact analysis that can be conducted at a general or more detailed level, as required, and shows how the project will affect the three dimensions of sustainability whilst identifying conflicting goals;

- it offers an explicit assessment of the impacts that have been identified, using specific self-determined criteria and weights, such that it can demonstrate whether any of the established criteria have trends that are irreversible.

Qualifications:

- this paper includes only two cases, this may have limited the results, as different case studies may have encountered different success criteria other than the A92 and Newport Southern Distributor Road (NSDR) projects;

- the fact that DBFO is a fairly new procurement system limits the amount of information and research that is available;

- a limited number of organizations are involved with DBFO contracts, which again limits the research information;

- the reluctance of interviewees to divulge confidential information may have restricted the research into drawing deeper results and conclusions.

\section{Conclusion}

The traditional procurement methods in general target the achievement of the most economical solution for the clients of the projects. Yet a sustainable approach will require the satisfaction of two other pillars, namely the social and environmental pillars, other than the economical pillar. In this respect, the paper, based on case study research, explained the sustainability implementation in two PFI road projects and demonstrated that the PFI mechanism facilitates sustainable implementation to a far greater extent than is achievable using traditional procurement methods.

In conclusion, this paper presented an examination of the sustainability of PFI, which indicates that PFI is a viable sustainable approach, and also offers an instrument that can be developed to further enhance the accuracy of future sustainability studies, and offers an approach to comparisons between alternative procurement approaches.

\section{References}

Akbiyıkl1, R. 2005. The Holistic Realisation of PFI Road Project Objectives in the UK. Research Centre for the Built and Human Environment, School of Construction and Property Management, Unpublished PhD Thesis. University of Salford, Salford, UK.

Akbıyıklı, R.; Dikmen, S. U.; Eaton, D. 2011. Financing road projects by private finance initiative: current practice in the UK with a case study, Transport 26(2): 208-215.

http://dx.doi.org/10.3846/16484142.2011.589426

Akbiyıklı, R.; Eaton, D. 2005. Lessons learned from two PFI road projects in the UK, in Proceedings of the Third International Conference on Construction in the $21^{\text {st }}$ Century CITC-III. Ahmed, S. M.; Ahmad, I.; Pantouvakis, J. P.; Zheng, J. (Eds.). Sept. 15-17, 2005. Athens, Gr. 
BRE. 2002. Reputation, Risk and Reward - the Business Case for Sustainability in the UK Property Sector: A Report by the Sustainable Construction Task Group, Building Research Establishment (BRE). UK.

CIB. 1999. Agenda 21 on Sustainable Construction, CIB Report Publication 237, CIB. Rotterdam, Nederland.

CIRIA. 2001. Sustainable Construction Procurement, Report CIRIA C571: A Guide to delivering environmentally responsible projects. London, UK.

CIRIA. 2006. Sustainable Perspectives. Available from Internet: www.ciria.org/pdf/newsletter_sustainability.pdf

DEFRA. 2010. Strecthing the Web. The UK Government Department for Environment, Food and Rural Affairs. Available from Internet: http://stretchingtheweb.defra.gov.uk/

DETR. 2000. Building a Better Quality of Life - A strategy for More Sustainable Construction, Dept. of the Environment, Transport and the Regions (DETR). London, UK.

Ding, G. K. C. 2008. Sustainable construction - the role of environmental assessment tools, Journal of Environmental Management 86: 451-464. http://dx.doi.org/10.1016/j.jenvman.2006.12.025

DTI. 2004. Sustainable Construction Brief 2, Dept. of Trade and Industry (Currently Dept. of Business Skills and Innovation), Sustainable Construction Team. London, UK.

DTI. 2006. Review of Sustainable Construction, Dept. of Trade and Industry, October. London, UK.

Eaton, D.; Akbiyikli, R. 2005. Quantifying Quality. Available from Internet: www.rics.org/NR/rdonlyres/ A37E17C2-C4FC-4F50-AE40-14F62E949BD3/0/PFI_Report.pdf

Edelenbos, J.; Klijn, E. H. 2009. Project versus process management in public private partnership: relation between management style and outcomes, International Public Management Journal 12(3): 310-331. http://dx.doi.org/10.1080/10967490903094350

FIEC. 2005. FIEC Principles for Sustainability, European Construction Industry Federation. Bruxelles, Belgium.

Green Alliance. 2004. PFI: Meeting the Sustainability Challenge, Green Alliance. London, UK.

Highways Agency. 2004. DBFO - Value in Roads: Road Projects - Design, Build, Operate \& Finance. Available from Internet: www.highways.gov.uk/roads/dbfo/dbfo_about.htm

HM Treasury Taskforce. 1999. How to Account for PFI Transactions', Technical Note 1, Office of Government Commerce (OGC). UK.

HMRC. 2011. HM Revenue and Customs, UK. Available from Internet: http://www.hmrc.gov.uk/index.htm

Hill, R. C.; Bowen, P. A. 1997. Sustainable construction: principles and a framework for attainment, Construction Management and Economics 15(3): 67-76. http://dx.doi.org/10.1080/014461997372971

Hood, C. 1995. The new public management in the 1980s: variations on the theme, Accounting, Organisations and Society 20(2/3): 93-100. http://dx.doi.org/10.1016/0361-3682(93)E0001-W

Howard, N. 2000. Sustainable Construction - the Data. Building Research Establishment (BRE).

Kibert, C. 1999. Reshaping the Built Environment: Ecology, Ethics and Economics. Washington, DC: Island Press.

Mickaityte, A.; Zavadskas, E. K.; Kaklauskas, A.; Tupenaite, L. 2008. The concept model of sustainable buildings refurbishment, International Journal of Strategic Property Management 12(1): 53-68. http://dx.doi.org/10.3846/1648-715X.2008.12.53-68

Newport Matters. 2004. Newport City Council's Newspaper. Available from Internet: www.newport.gov.uk

OECD. 2010. Guidance on Sustainability Impact Assessment. Organisation for Economic Co-operation and Development. Paris, France.

Ortiz, O.; Castells, F.; Sonnemann, G. 2009. Sustainability in the construction industry: a review of recent developments based on LCA, Construction and Building Materials 23: 28-39.

http://dx.doi.org/10.1016/j.conbuildmat.2007.11.012 
Parkin, S. 2000. Context and drivers for operationalizing sustainable development, in ICE November: 9-15.

Robichaud, L. B.; Anantatmula, V. S. 2011. Greening project management practices for sustainable construction, ASCE, Journal of Management in Engineering 27(1): 48-57. http://dx.doi.org/10.1061/(ASCE)ME.1943-5479.0000030

Rodman, D. M.; Lenssen, N. 1995. A Building Revolution: How Ecology and Health Concerns are Transforming Construction, Worldwatch Paper 124.

Rwelamila, P. D.; Talukhaba, A. A.; Ngowi, A. B. 2000. Project procurement systems in the attainment of sustainable construction, Sustainable Development 8: 39-50. http://dx.doi.org/10.1002/(SICI)1099-1719(200002)8:1<39::AID-SD127>3.0.CO;2-Z

Saparauskas, J.; Turskis, Z. 2006. Evaluation of construction sustainability by multiple criteria methods, Technological and Economic Development of Economy 12(4): 321-326.

Swiss Federal Council. 2008. Sustainability Assessment - Guidelines for Federal Agencies and Other Interested Parties.

The Earth Summit. 1992. United Nations Conference on Environment and Development (UNCED), Rio de Janeiro, Brazil. Available from Internet: www.un.org/geninfo/bp/enviro.html

UN Report A/42/427 (Brundtland Report). 1987. Our Common Future, Report of the World Commission on Environment and Development, United Nations Assembly.

UN World Summit. 2005. UN Sixtieth Session, UN General Assembly, A/60/L.1. Available from Internet: www.un.org/summit2005/

Viteikiene, M.; Zavadskas, E. K. 2007. Evaluating the sustainability of Vilnius city residential areas, Journal of Civil Engineering and Management 13(2): 149-155.

Wang, N. 2011. Risk allocation in the operational stage of private finance initiative projects, Journal of Performance of Constructed Facilities, ASCE 25(6): 598-605. http://dx.doi.org/10.1061/(ASCE)CF.1943-5509.0000194

WRAP. 2003a. Comparative Performance - Newport Southern Distributor Road, the Waste and Resources Action Programme. Banbury, Oxon.

WRAP. 2003b. Newport Southern Distributor Road: Construction \& Maintenance PFI, the Waste and Resources Action Programme. Banbury, Oxon. Available from Internet: www.aggregain.org.uk/ procurement/case_studies/newport_southern.html

WRAP. 2004a. The Big Picture: Specifying Recycled in Local Authority Contracts for Highways Maintenance, the Waste and Resources Action Programme. Banbury, Oxon, July.

WRAP. 2004b. Case Study: Performance of Recycled and Secondary Aggregates in the Construction of the Newport Southern Distributor Road, the Waste and Resources Action Programme. Banbury, Oxon.

Yuan, J.; Zeng, A. Y.; Skibniewski, M. J.; Li, Q. 2009. Selection of performance objectives and key performance indicators in public-private partnership projects to achieve value for money, Construction Management and Economics 27(3): 253-270. http://dx.doi.org/10.1080/01446190902748705

Yuan, J.; Skibniewski, M. J.; Li, Q.; Zheng, L. 2010. Performance objectives selection model in public-private partnership projects based on the perspective of stakeholders, Journal of Management in Engineering 26(2): 89-104. http://dx.doi.org/10.1061/(ASCE)ME.1943-5479.0000011

Rifat AKBIYIKLI is an Assistant Professor at Sakarya University, Turkey. He holds a MSc in Civil Engineering from the Norwegian University of Science and Technology (NTNU), a MSc in Construction Management from the University of Bath and a Ph.D. in Construction Management from the University of Salford. His research interests include PFI/PPP in infrastructures, construction project management, technical and economical issues in transportation projects, performance and productivity in construction projects, construction procurement, innovation in construction, disaster management and $\mathrm{H} \& \mathrm{~S}$ in construction. His Ph.D. thesis is on PPPs which has published extensively in this field. Dr Akbiyıklı has also published three books in the field of Construction Management. 
David EATON is currently a Professor of Construction Economics and Finance in the School of the Built Environment at the University of Salford. He is a Chartered Quantity Surveyor by professional discipline. He has been an advisor to national and regional governments in Turkey, the Czech Republic and Portugal on the introduction of PFI. He has published over 100 papers and articles on project management and project finance.

Seyyit Umit DIKMEN is an Assistant Professor in Civil Engineering Department at Istanbul Kultur University, Turkey. He holds MSc and PhD degrees from the University of Illinois, Urbana-Champaign. Dr Dikmen has also extensive construction industry experience, including middle and top level management positions at Turkish and International construction companies. His research interests include soft computing methods, computer methods in civil engineering, construction management, cost estimation and control and earthquake engineering. He has authored numerous papers and reports in the fields of his interest. 